\title{
Evaluation of rapeseed cultivation suitability in Apulia with GIS-multicriteria analysis
}

\author{
Nicola Grassano, Luigi Tedone, Leonardo Verdini, Giuseppe De Mastro \\ Dipartimento di Scienze delle Produzioni Vegetali, Università degli Studi di Bari Aldo Moro, Italy
}

\begin{abstract}
The potential of land for energy crops is determined by an evaluation of biophysical and economical variables. From this respect, climate, soil and geomorphologic environmental components are the most important agro-ecological variables to conduct this kind of evaluation. In this study, Geographic Information System (GIS) has been used to identify the most suitable areas for rapeseed crop production in the Apulia region. Environmental components such as climate (precipitation, temperature), soil (chemical and physical characteristics including texture, gravel percentage, $\mathrm{pH}$, electrical conductivity (EC), soil depth, etc.), topography (slope) and economical components (farm-useful surface, mechanization, percentage of land covered by cereals and horticulture, irrigated surface, set-aside surface) were considered. Biophysical parameters (climate, geomorphology and soil) were used to draw a map of agronomic suitability of rapeseed according to the Agronomic Classification of the Territory II (CAT II) classification system; a map of general suitability of rapeseed in the Apulia region has been drawn with the support of multicriteria analysis, which also takes into account the economical parameters. The results from overlay maps for agronomic evaluation in the Apulia region showed that $38 \%$ (189,983 ha) of the arable land area is highly suitable (S1), $43.4 \%$ (21,6642 ha) is moderately suitable (S2), $11.9 \%(59,487$ ha) is marginally suitable (S3) and $6.7 \%(33,210 \mathrm{ha})$ is and not suitable (N) for rapeseed cultivation.
\end{abstract}

Correspondence: Giuseppe De Mastro, Dipartimento di Scienze delle Produzioni Vegetali, Università degli Studi di Bari Aldo Moro, p.zza Umberto I, 1 - 70121 Bari, Italy.

Tel. +39.080 .5443043 - Fax number +39.080 .5442976 .

E-mail: demastro@agr.uniba.it

Key words: Brassica napus, energy crop, Geographic Information System, land suitability.

Acknowledgements: we gratefully acknowledge the Regional Association of Consortiums for the Protection of Apulia (Assocodipuglia) and Ing. Giuseppe Procino of Planetek Italia S.p.a for technical assistance.

Received for publication: 8 October 2010.

Accepted for publication: 12 February 2011.

(C) Copyright N. Grassano et al., 2011

Licensee PAGEPress, Italy

Italian Journal of Agronomy 2011; 6:e16

doi:10.4081/ija.2011.e16

This work is licensed under a Creative Commons Attribution NonCommercial 3.0 License (CC BY-NC 3.0).
The GIS-multicriteria elaboration of the environmental factors together with structural components of Apulian farms showed that the province of Foggia represents $54.5 \%$ of the provincial arable land, whereas the province of Bari (28.8\%) has large extent of suitable area for the cultivation of rapeseed for energy use.

\section{Introduction}

Nowadays, cultivation of energy crops plays a key role as a source of renewable energy, which has been confirmed by the recent Directive 2009/28/EC published in 0J 5.6.2009 and the Commission Decision of 30.6.2009 on National Renewable Energy Action Plans, aiming at reaching the EU environmental and energetic targets within 2020.

On the other hand, the low price of some agricultural products drives the research of new alternative use of the crops, in particular toward energy production direction. In the Apulia region, in south Italy, the results showed that a high percentage of arable land has been used for cereal crops, where durum wheat is the most widely grown crop. Unfortunately, the typical Mediterranean climate reduces the possibility for some energy crops to be introduced. Rapeseed oil crop, on the other hand, has recently been exploited to boost some cultivation areas all over the world as in Italy, especially in some regions of northern part of Italy because of the great interest for the use of oil in the production of biodiesel or crude vegetable oil for the cogeneration. Rapeseed (Brassica napus L. var. oleifera D.C.) is a species that belongs to Brassicaceae family, containing both high oil and protein content in seed. In Apulia, researches and demonstrative activities about the rapeseed showed that there is possibility to introduce the crop in this area (De Mastro et al., 2009; Lazzeri et al., 2009). Food crops have obviously to remain the first source of income for the national and regional agricultural sector, but energy crops cultivated in rotation with food crops, can contribute to increase biodiversity at farm level and improve consequently the qualitative and quantitative aspects of yields of crops in sequence.

The potential of land for agricultural use is determined by an evaluation of the climate, soil and topographical environmental components and the understanding of local biophysical restraints. In the last few years, territorial studies have been developed thanks to the modern management system of geographical data called Geographic Information Systems (GIS). GIS is a powerful set of tools for collecting, storing, retrieving, transforming and displaying spatial data from the real world (Burrough, 1986; Tomlin, 1990). It has the ability to perform numerous tasks utilizing both spatial and attribute data.

One of the most useful features of GIS is the ability to overlay different layers or maps. For this reason, GIS can be considered a powerful tool to assess the suitability of a crop at a territorial level, as for energy crop (Sabbatini et al., 2004; Pellerano et al., 2007; Ghasemi Pirbalouti, 2009).

The aim of this study was to assess the land suitability for rapeseed 
cultivation in the Apulia region by integrating various kind of information with spatial analysis technique. Firstly, suitability map were obtained assessing environmental parameters of the territory; then, biophysical parameters were integrated together with structural indicators of the farms, using multicriteria analysis to draw a general map of adaptability. The results from this study could be an important tool to support planners in taking the right decisions about the energy and agricultural policy of the region.

\section{Materials and Methods}

The first phase of the work was the collection and storage of regional data in the software ArcGIS Desktop 9.2 (ESRI).

Climatic information was obtained from 188 meteorological stations located within the study area and the surrounding zones, provided by the Regional Association of Consortiums for the Protection of Apulia (Assocodipuglia), regarding daily minimum, medium and maximum temperature and precipitation. Data were collected at the meteorological stations in a period ranging from 20 to over 60 years. Daily average values for each variable were calculated.

Moreover, data about soil physical and chemical characteristics (texture, gravel percentage, $\mathrm{pH}$, electrical conductivity (EC), soil depth, organic matter, total carbonate content, period of water logging) were picked up from a regional study about the agroecological characterization of the Apulia region (Caliandro et al., 2005), and average values of each soil parameters were calculated and assigned to the homogeneous soil areas (cartography units) used by Caliandro et al. (2005) as polygons of the map constituted by soils with similar taxonomy. Slope and land use (deriving from CORINE Project) were obtained from the Territorial Information Systems of the Apulia region (www.cartografico.puglia.it). All the data were geo-referenced using a metric Universal Transverse Mercator (UTM) coordinate system, WGS84 (World Geodetic System 84), zone 33N. Meteorological database allowed to define two climatic indicators: Crop-specific thermal index (CTI) and Seasonal Rainfall Deficit (SRD) (Giardini et al., 1997). The CTI indicator was calculated on the basis of thermal requirement of rapeseed; base temperature (min for development) of $0^{\circ} \mathrm{C}$ and optimum temperature of $18^{\circ} \mathrm{C}$ (De Mastro and Bona, 1998), and heat stress temperature of rapeseed of $30^{\circ} \mathrm{C}$ (Morrison and Stewart, 2002) were also used.

The first step was the calculation of Monthly Thermal Index (MTI) for each month of the crop cycle, according to the following procedure (Giardini et al., 1997):

MTI $=(\mathrm{x}-\mathrm{B})(\mathrm{x}-\mathrm{L})^{*}[(\mathrm{~B}+\mathrm{L}-2 \mathrm{~T})(\mathrm{x}-\mathrm{T})+(\mathrm{T}-\mathrm{B})(\mathrm{T}-\mathrm{L})] /(\mathrm{T}-\mathrm{B})^{2}(\mathrm{~T}-\mathrm{L})^{2}$

where

$\mathrm{X}=$ average monthly temperature of the site

$\mathrm{B}=$ base temperature

$\mathrm{L}=$ heat stress temperature

$\mathrm{T}=$ optimum temperature

The MTI ranged between 0 and 1. The MTI values of every month were added and the results were divided by the number of month, to obtain the CTI of rapeseed for every meteorological site.

The second climatic indicator was the Seasonl Rainfall Deficit (SRD), which has been defined as the difference between the precipitation of a specific site and the evapotranspiration of the crop during the critical period of plant life cycle (March-April-May in the case of rapeseed).

In particular, the method proposed by Hargreaves (Hargreaves and Samani, 1985; Hargreaves et al., 1985) has been used to calculate the reference evapotranspiration according to the following formula:

$E T_{0}=0.0023^{*} R_{a}^{*}\left(T_{\text {med }}+17.8\right)\left(T_{\max }+T_{\text {min }}\right)^{0.5}$ where

$E T_{0}=$ reference evapotranspiration $(\mathrm{mm} / \mathrm{d})$

$\mathrm{T}_{\min }=$ daily minimum temperature $\left({ }^{\circ} \mathrm{C}\right)$

$\mathrm{T}_{\max }=$ daily maximum temperature $\left({ }^{\circ} \mathrm{C}\right)$

$\mathrm{T}_{\text {med }}=$ daily average temperature $\left({ }^{\circ} \mathrm{C}\right)$

$\mathrm{R}_{\mathrm{a}}=$ extra atmospheric radiation expressed in equivalent evaporation (mm/d) (Doorenbos and Pruitt, 1977; Hargreaves, 1994).

Crop coefficients $(\mathrm{kc})$ of every growth stage were derived from FAO paper n. 56 (Allen et al., 1998).

The values of climatic indicators obtained from each meteorological site were elaborated through the process of geo-statistical interpolation Inverse distance weighted, in the Spatial Analyst tool of ArcMap. This process had to be interpreted to geo-referenced information (from punctual to spatial information) in order to obtain maps of the different indicators in the Apulia region.

Concerning the soil, each parameter value was assigned to homogeneous soil area to achieve the total covering of the region for examined physical and chemical characteristics. This gave us the possibility to achieve the graph results of all the maps concerning biophysical components of the Apulia region.

In order to evaluate environmental suitability of oilseed rape, a classification system has been used as defined by the CAT II system (Giardini et al., 1997). The methodology is based on the assignment of restriction score given to biophysical components (Table 1), which reduces the productivity. It allowed to individuate 10 agronomical classes, in relation to the total restriction score of each area for the specific crop (rape in the specific case); whereas agronomical classes were grouped in 4 classes according to the suitability of the crop (Table 2): i) highly suitable (S1), restriction scores were less than $30 \%$ while agronomical values were higher than $70 \%$; ii) moderately suitable (S2), restriction score ranged from 30 to $60 \%$, whereas agronomical values ranged from 40 to $70 \%$; iii) marginally suitable (S3), restriction score ranges from 60 to $90 \%$, and agronomical value ranged from 10 to $40 \%$; iv) not suitable (N), in which restriction score was higher than $90 \%$.

All the maps of the biophysical components were elaborated in GIS software for the reclassification process, with the aim to assign at every map point the restriction score deriving from the values of each parameter at that specific point.

Finally, after the sum of all restriction scores of each parameter, a final map of agronomical suitability of rapeseed in the Apulia region, according to the CAT II classification system, was obtained. This final map, including all regional area, was compared to the map of Land Use in the GIS project. This comparison was necessary to exclude areas where we can not grow rapeseed crop such as urban areas, forests, orchards including olive trees, vineyards, etc.

The second aim of this study was to integrate the ecological map with farm-structure indicators, to allow locating areas in Apulia with enough high potentiality to introduce the rapeseed in the regional cropping systems.

This was made by adopting a multicriteria approach in the GIS project (Malczewski, 2000), taking into account, in addition to ecological indicators, the farm-structure indicators, at municipality level (V General Census of Agriculture, 2010 available from: www.istat.it), as follows:

- farmland $>5$ ha/total municipal farmland; it expresses the land percentage of farm size greater than 5 hectares over the total municipal farmland; so that it indicates the presence of farm in the municipality with an appropriate extent of land for energy crop;

- total municipal farmland/municipal area; it indicates the importance of agriculture in the municipality in respect to other municipality's production activities.

- municipal set aside area /municipal arable area; this indicator was adopted because of the possibility to grow energy crops in set-aside 
Table 1. Restriction score (CAT II classification method).

\begin{tabular}{|c|c|c|c|}
\hline Environmental characteristics & Scores & Environmental characteristics & Scores \\
\hline $\begin{array}{l}\text { Pedology } \\
\text { Depth }(\mathrm{cm}) \\
60-100 \\
25-60 \\
<25\end{array}$ & $\begin{array}{l}10 \\
30 \\
42\end{array}$ & $\begin{array}{c}\text { Salinity (Ece mS/cm) } \\
2-4 \\
4-8 \\
8-12 \\
12-16 \\
>16\end{array}$ & $\begin{array}{c}5 \\
16 \\
25 \\
60 \\
80\end{array}$ \\
\hline $\begin{array}{l}\text { Gravel (\% of soil weight) } \\
5-20 \\
20-40 \\
40-70 \\
70-90 \\
<90\end{array}$ & $\begin{array}{l}19 \\
39 \\
55 \\
65 \\
90\end{array}$ & $\begin{array}{c}\text { Hydrology } \\
\text { Drainage } \\
\text { Moderately well drained } \\
\text { Somewhat excessively drained } \\
\text { Somewhat poorly drained } \\
\text { Excessively drained }\end{array}$ & $\begin{array}{c}7 \\
15 \\
20 \\
30\end{array}$ \\
\hline $\begin{array}{l}\text { Texture } \\
\text { Loam } \\
\text { Clay loam, sandy clay loam } \\
\text { Clay silty, sandy clay } \\
\text { Clay } \\
\text { Clay (with clay percentage }>60 \text { ) } \\
\text { Silt loam } \\
\text { Silt } \\
\text { Sandy loam } \\
\text { Sand }\end{array}$ & $\begin{array}{c}0 \\
5 \\
5 \\
16 \\
30 \\
10 \\
25 \\
12 \\
35\end{array}$ & $\begin{array}{c}\text { Poorly drained } \\
\text { Very poorly drained } \\
\text { Geological characteristics } \\
\text { Slope (S) } \\
0.5-1.3 \\
1.3-2.8 \\
2.8-5.0 \\
5.0-9.1 \\
>9.1\end{array}$ & $\begin{array}{c}8 \\
20 \\
40 \\
65 \\
90\end{array}$ \\
\hline $\begin{array}{l}\text { Organic matter }(\%) \\
25-50 \\
>50\end{array}$ & $\begin{array}{l}10 \\
20\end{array}$ & $\begin{array}{c}\text { Climate } \\
\text { Crop-specific thermal index } \\
0.7-0.8 \\
0.6-0.7\end{array}$ & $\begin{array}{c}3 \\
13\end{array}$ \\
\hline $\begin{array}{l}\text { Total carbonate (\%) } \\
25-50 \\
>50 \\
\mathrm{pH} \\
5.8-6.5 \\
5.0-5.7 \\
<5.0 \\
7.4-8.2 \\
8.3-9.0 \\
>9.0 \\
\end{array}$ & $\begin{array}{c}7 \\
16 \\
\\
8 \\
10 \\
20 \\
5 \\
10 \\
20\end{array}$ & $\begin{array}{c}0.5-0.6 \\
0.4-0.5 \\
0.3-0.4 \\
0.2-0.3 \\
<0.2 \\
\text { Seasonal rainfall deficit }(\mathrm{mm}) \\
100-200 \\
200-300 \\
>300\end{array}$ & $\begin{array}{l}32 \\
52 \\
70 \\
90 \\
95\end{array}$ \\
\hline
\end{tabular}

Ece, electrical conductivity of a saturated soil paste extract; S, $10.8 \sin \Theta+0.03$ for slope $<9 \%$, S, $16.8 \sin \Theta-0.50$ for slope $\geq 9 \%$.

areas;

- number of tractors with power $>60 \mathrm{~kW} /$ municipal area; it represents an index of farm mechanization;

- municipal cereals area/municipal arable area; it indicates the presence of cereals in the municipality, which are the main crop cultivated in rotation with rapeseed;

- municipal horticulture area/municipal arable area; the presence of vegetables makes the conversion of land for energy crops more difficult;

- municipal irrigated area/total municipal farmland; irrigation usually used for intensive cropping system; in addition to that, irrigation use influences the energetical balance of energy crops.

All indicators are referred to a municipal scale. These maps were subsequently submitted to the Reclassify tool in ArcGIS. In this standardization process, the maps had to be converted from farm-economical indicator into a scale of values ranging from 1 to 10 , as the biophysical indicators, avoiding problems of calculation related to different measure units.

The methodology of multicriteria analysis (Saaty, 1980) was applied assigning to each indicator a weight, ranging from 0 to 1 , according to the estimation of their influence on the rapeseed cultivation suitability. (Table 3 ). The assignment of weights was made with a matrix deriv-
Table 2. Suitability and agronomic classes, agronomic value and restriction score according to CAT II classification.

\begin{tabular}{lccc}
$\begin{array}{l}\text { Suitability } \\
\text { classes }\end{array}$ & $\begin{array}{c}\text { Agronomic } \\
\text { classes }\end{array}$ & $\begin{array}{c}\text { Agronomic } \\
\text { value }\end{array}$ & $\begin{array}{c}\text { Restriction } \\
\text { score }\end{array}$ \\
S1 & I & $>90-100$ & $0-9.9$ \\
S1 & II & $>80-90$ & $10-19.9$ \\
\hline S1 & III & $>70-80$ & $20-29.9$ \\
S2 & IV & $>60-70$ & $30-39.9$ \\
\hline S2 & V & $>50-60$ & $40-49.9$ \\
S2 & VI & $>40-50$ & $50-59.9$ \\
S3 & VII & $>30-40$ & $60-69.9$ \\
S3 & VIII & $>20-30$ & $70-79.9$ \\
\hline S3 & IX & $>10-20$ & $80-89.9$ \\
N & X & $0-10$ & $90-100$ \\
\hline
\end{tabular}

S1, highly suitable; $\mathrm{S}$, moderately suitable; $\mathrm{S}$, marginally suitable; $\mathrm{N}$, not suitable. 
ing from a paired comparison method, using the value of the scale of Saaty ( $1=$ =qual; $3=$ moderate; $5=$ strong; $7=$ =very strong; $9=$ =xtreme), which expresses the dominance of one indicator in comparison with the other ones. Biophysical indicators were considered together as one layer, called CAT II, as the map deriving from the described classification process CAT II.

All layers, after the assignment of the weights, were combined through GIS in the Raster calculator that allowed performing mathematical calculations using operators and functions on raster layers; the considered territorial unit was a cell of $100 \times 100 \mathrm{~m}$; the tool performed each pixel using the following formula:

$A_{i}=\sum_{j} w_{j} x_{i j}$

where

$A_{i}=$ final value of the cell $\mathrm{i}$

$w_{j}=$ weight of indicator $\mathrm{j}$

$x_{i j}=$ value of indicator $\mathrm{j}$ in the cell $\mathrm{i}$

So a regional map of rapeseed cultivation suitability was obtained clustering the area in 4 classes (optimum, good, sufficient, insufficient).

\section{Results and Discussion}

The map for the SRD of rapeseed showed a certain variability along the regional area, with values ranged from a min of $-3.4 \mathrm{~mm}$ (no deficit) to a max of $279.0 \mathrm{~mm}$. Considering the CTI (range from 0 to 1), the results were close to the value of thermic requirements of the species. In fact, the max value was $C T I=0.88$; the other values, in most of areas in the south of the region, were similar, and only in the coldest area of the Gargano's Promontory the indicator reached the min value of 0.42 . With regard to soil parameters, map of soil depth showed the main restriction in the area of Murgia and Gargano's Promontory; in the same areas another limitation resulted gravel content. The texture map indicated that in clay areas this component could represent a small restriction for the crop, where organic matter, total carbonate content and salinity did not show anomalous levels. Soil $\mathrm{pH}$, on the other hand, showed a certain alkalinity in the areas of Tavoliere and Murgia, while restrictions derived from drainage were located in some small areas of Foggia province and of Salento's zone.

From the results of overlay maps for biophysical (climate, geomorphology and soil variables) suitability evaluation using CAT II classification method, we were able to classify $38.0 \%\left(1899.83 \mathrm{~km}^{2}\right), 43.4 \%$ $\left(2166.42 \mathrm{~km}^{2}\right), 11.9 \%\left(594.87 \mathrm{~km}^{2}\right)$ and $6.7 \%\left(332.10 \mathrm{~km}^{2}\right)$ of the total regional arable land as highly suitable (S1), moderately suitable (S2), marginally suitable (S3) and not suitable (N), respectively (Figure 1).

At provincial level, the map showed that most of areas classified as S1 belongs to the province of Foggia (38.2\% of provincial arable land, $1388.86 \mathrm{~km}^{2}$ ), where the analysis showed large extension of land with restriction of little importance caused by soil alkalinity and SRD. In the province of Bari, the extension of the land in the same class was 251.65 $\mathrm{km}^{2}$, corresponding to $17.2 \%$ of provincial arable land. The potential suitable areas decreased passing to the province of Brindisi (107.31 $\mathrm{km}^{2}$ ), Lecce $\left(97.12 \mathrm{~km}^{2}\right)$ and Taranto $\left(54.90 \mathrm{~km}^{2}\right)$. As regards to the zone classified in the class S2, also in this case the province of Foggia showed the largest area with $929.98 \mathrm{~km}^{2}$ (25.6\% of provincial arable land), followed by Bari (583.16 km², 40.0\% of provincial arable land), then Lecce, Taranto and Brindisi with 317.50, 256.92 and $78.85 \mathrm{~km}^{2}$, respectively (Table 4$)$.

Multicriteria analysis (Figure 2) gave us the possibility to determine the locations of the suitable areas for the cultivation of rapeseed in the
Table 3. Indicators and relative weights.

\begin{tabular}{lc} 
Indicator & Weight \\
Agro-ecological & \\
$\quad$ Climate, pedology and slope (CAT II) & 0.491 \\
Structural & \\
$\quad$ Farmland > 5 ha / total municipal farmland & 0.109 \\
Total municipal farmland / municipal area & 0.055 \\
Municipal set aside area / municipal arable area & 0.036 \\
Number of tractors with power > 60 kW / municipal area & 0.073 \\
Municipal cereals area/ municipal arable area & 0.109 \\
Municipal horticulture area / municipal arable area & 0.036 \\
Municipal irrigated area / total municipal farmland & 0.091 \\
\hline
\end{tabular}

Table 4. CAT II classification of arable land for rapeseed cultivation in Apulia region (in hectares).

\begin{tabular}{lcccc} 
Province & S1 & S2 & S3 & N \\
Foggia & 138,900 & 93,000 & 36,100 & 32,400 \\
Bari & 25,200 & 58,300 & 17,200 & 0.8 \\
\hline Brindisi & 10,700 & 7900 & 0 & 0 \\
Taranto & 5500 & 25,700 & 6100 & 0 \\
\hline Lecce & 9700 & 31,800 & 0 & 0 \\
Total & 190,000 & 216,600 & 59,500 & 33,200 \\
\hline
\end{tabular}

S1, highly suitable; S2, moderately suitable; S3, marginally suitable; N, not suitable.

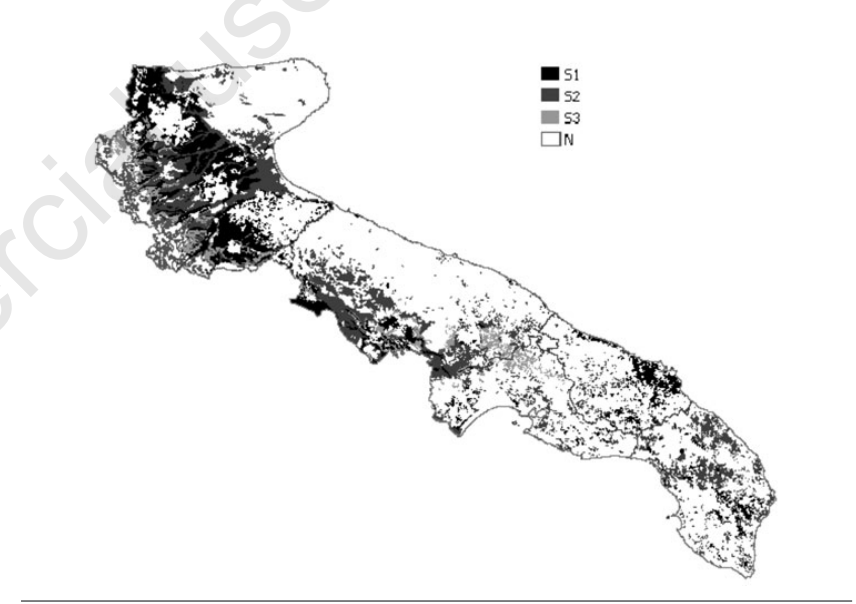

Figure 1. Map of agrarian suitability for rapeseed. S1, highly suitable; S2, moderately suitable; S3, marginally suitable; $N$, not suitable.

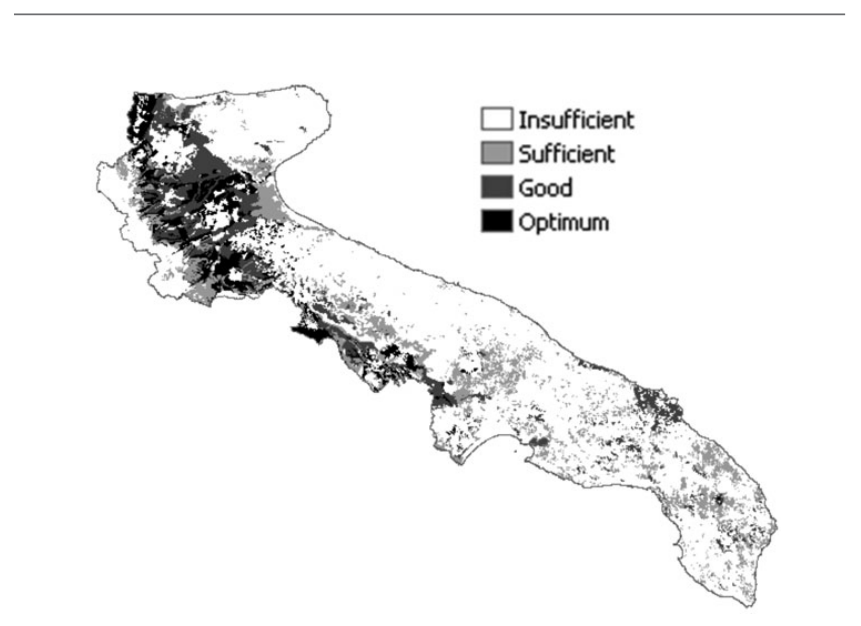

Figure 2. Map of territorial adaptability of Apulia region for the cultivation of rapeseed. 
Table 5. GIS-multicriteria classification of rapeseed potential adaptability in Apulia region (in hectares).

\begin{tabular}{lccccc} 
Province & Optimum Cood Sufficient & Insufficient & $\begin{array}{c}\text { Classes } \\
\text { Total } \\
\text { arable land }\end{array}$ \\
Foggia & 93,000 & 104,900 & 31,000 & 134,200 & 363,100 \\
Bari & 20,900 & 21,200 & 7600 & 96,200 & 145,900 \\
\hline Brindisi & 0 & 9400 & 3500 & 22,400 & 35,400 \\
Taranto & 1100 & 11,200 & 15,500 & 28,100 & 55,900 \\
\hline Lecce & 200 & 5600 & 26,900 & 19,700 & 52,400 \\
Total & 115,200 & 152,400 & 84,600 & 300,500 & 652,700 \\
\hline
\end{tabular}

region. In fact, about $54.5 \%$ of arable land $\left(1980 \mathrm{~km}^{2}\right)$ in the province of Foggia has been classified as optimum or good for the introduction of the species (Table 5), correlated not only to favourable biophysical variables, but also to farm-structure factors as farm size, presence of mechanization, diffusion of extensive cropping system and set-aside areas, which could create good conditions for the introduction and the development of the crop in this area.

High values of adaptability were also recorded in the case of the province of Bari as consequence of farm-structure indicators, which means that rape could easily be grown in rotation with the most relevant crops of the area.

In relation to that, the surfaces of Bari decreased in respect to Foggia, to the $28.8 \%$ of arable land $\left(420 \mathrm{~km}^{2}\right)$, but showed a range of adaptability in the classes of optimum and good depending mainly from the soil characteristics related to soil depth, gravel content and bad drainage.

In the rest of Apulian region, the extent of arable land defined as optimum for rapeseed cultivation, strongly decreased because of many factors related to soil characteristics (low depth, high percentage of gravel, drainage) and climatic condition (SRD), but above all economical variables, depending from land extension, presence of intensive cropping systems, use of irrigation for horticulture and orchards. In all the studied areas, maps showed the superiority of area with sufficient suitability, while arable land surfaces with a good adaptability are restricted to value from $10 \%$ (province of Lecce, $56 \mathrm{~km}^{2}$ ) to $26 \%$ (Brindisi, $94 \mathrm{~km}^{2}$ ).

\section{Conclusions}

This study confirmed that the methodology based on GIS was adequate to integrate database of climate, soil and topography factors with different spatial and temporal resolutions, which allowed us evaluating the agricultural systems. Besides, the application of CAT II classification method gave us detailed information about the suitability of the area studied for the cultivation of rapeseed.

The results of this study showed that rapeseed could be easily introduced in a cereal farming systems that is widespread on the regional territory, especially in non-irrigated areas of the provinces of Foggia and Bari. This investigation provided data at a regional level, which could be useful to farmers to select their crop pattern. In fact, the introduction of oil energy crop in suitable areas can also promote the traditional cultivation methods of cereals in the region, which play a fundamental role in improving the quality of food production and, at the same time, create a further source of income.
The adoption of multicriteria analysis permitted to verify the efficacy of this approach in the study of cropping systems, and allowed integrating biophysical and economical components in the suitability basis evaluation.

However, the data presented here offer a useful background for more detailed territorial studies of the energy crops cultivation suitability to support the decision-makers for planning of agricultural and energy policy in the Apulia region.

\section{References}

Allen R.G., Pereira L.S., Raes D., Smith M., 1998. Crop evapotranspiration - Guidelines for computing crop water requirements - FAO Irrigation and Drainage, Paper 56, Roma, Italy.

Burrough P.A., 1986. Principles of Geographical Information Systems for Land Resources Assessment. Clarendon Press, Oxford, UK.

Caliandro A., Lamaddalena N., Stelluti M., Steduto P., 2005. Caratterizzazione agroecologica della Regione Puglia in funzione della potenzialità produttiva. Progetto ACLA 2. pp 179.

De Mastro, G., Bona, S., 1998. Colza (Brassica napus L. var. oleifera Metzg.). Oleaginose non alimentari. pp 29-35 in Collana PRisCA, a cura di G. Mosca. Edagricole, Bologna, Italy.

De Mastro G., Grassano N., Verdini L., Manolio G., 2009. Confronto tra sistemi colturali per la produzione di colza (Brassica napus L. var. oleifera) ad uso energetico. Atti $3^{\circ}$ Convegno nazionale Piante Mediterranee, Bari, Italy. Ital. J. Agron. 4(Suppl. 4):903-908.

Doorenbos J., Pruitt W.0., 1977. Crop water requirements, FAO Irrigation and Drainage. Paper 24, 2a ed., Roma, Italy.

Ghasemi Pirbalouti A., 2009. GIS-based land suitability evaluation for rapeseed oil crop. J. Food Agric. Environ. 7:837-840.

Giardini L., Borin M., Giupponi C., Bonini Baraldi A., 1997. La classificazione agronomica del territorio: proposta metodologica del sistema CAT II. Genio Rurale 5, pp 53-64.

Hargreaves G.H., 1994. Defining and using reference evapotranspiration. J. Irrig. Drain. E-ASCE 120:1132-1139.

Hargreaves G.H., Samani Z.A., 1985. Reference Crop Evapotranspiration from temperature. Appl. Eng. Agric. 1:96-99.

Hargreaves G.L., Hargreaves G.H., Riley J.P., 1985. Agricultural benefits for Senegal River Basin. J. Irrig. Drain. E-ASCE 111:113-124.

Lazzeri L., D’Avino L., Mazzoncini M., Antichi D., Mosca G., Zanetti F., Del Gatto A., Pieri S., De Mastro G., Grassano N., Cosentino S. L., Copani V., Ledda L., Farci R., Bezzi G., Lazzari A., Dainelli R., Spugnoli P., 2009. On Farm Agronomic and First Environmental Evaluation of Oil Crops for Sustainable Bioenergy Chains. Ital. J. Agron. 4:171-180.

Malczewski J., 2000. GIS and multicriteria decision analysis. John Wiley and Sons, New York, NY, USA.

Morrison M.J., Stewart D.W., 2002. Heat stress during flowering in Summer Brassica. Crop Sci. 42:797-803.

Pellerano A., Pantaleo A., Tenerelli P., Carone M.T, 2007. Studio per la valorizzazione energetica di biomasse agroforestali nella Regione Puglia. Dipartimento PROGESA, Università di Bari, Italy, pp 207.

Saaty T.L., 1980. The Analytical Hierarchy Process. McGraw Hill, New York, NY, USA.

Sabbatini T., Villani R., Bonari E., Galli M., 2004. Analisi territoriale delle colture da energia in Toscana. Quaderno ARSIA 6/2004.

Tomlin C.D., 1990. Geographic Information Systems and Cartographic Modeling. Prentice Hall, Upper Saddle River, NJ, USA. 